learn anything of its life history, as a number placed in a breeding cage failed to breed in confinement.

Monoptilota nubilella. On July 16 a number of lima bean plants, upon the stems of which were numerous galls, were sent to the department by Mr. Oscar L. Moore of Salisbury. They varied in length from $1 / 2$ inch to $1 \frac{1}{2}$ inches. An opening had been made by the larvæ in one end. Upon eutting into one of these galls, a beautiful bluish green larva was found to be responsible for their formation and the subsequent injury to the plants. The larva is a striking one in appearance, because of its uncommon metallic blue reflections. Several of the adults emerged from the galls and were identified as Monoptilota nubilella. A detailed account of this insect by Doctor Chittenden of the Bureau of Entomology may be found in Bulletin 23, new series, U. S. Department of Agriculture.

This pest was first found in the state in 1899 and has no doubt been responsible for more or less injury to lima bean plants since that time. No serious complaints of its injury came to the office, but should it become plentiful, it would no doubt be a hard pest to combat. The only means of control suggesting itself would be the removal of the galls from infested plants.

Thyridopteryx ephemeraeformis. This species of bag worm was responsible for a large amount of injury to fruit and shade trees the past season. Numerous inquiries as to its name and habits were received from widely separated localities in the state, showing that its occurrence was general. In many different places the writer saw evergreen trees, mostly arbor vitae in hedges, killed by it. Its attack was by no means confined to evergreens, however, for it was found on locust, blackberry, rose, maple, apple, plum and cherry. Young fruit trees seemed especially subject to its attack and trees in several young orchards visited were badly stripped.

Other pests of the season which were responsible for more or less damage but deserve no more than passing mention were: Army worm (Heliophila unipuncta), old-fashioned potato beetle (Epicauta vittata), bean leaf beetle (Ceratoma trifurcata), striped cucumber beetle (Diabrotica vittata), stalk borer (Hydroecia nitela), red humped apple worm (Schizura concinna), yellow-necked caterpillar (Datana ministra), and corn bill bugs (Sphenophorus sp.).

\title{
ENTOMOLOGICAL NOTES FOR 1907
}

By E. P. Felt, Albany, N. Y.

The climatic conditions of 1907 departed widely from those of normal years, and as a result the development of animal and plant life 
was exceptionally late. Warm weather finally came on very rapidly and all vegetation grew at such a rate that insects appeared unable to inflict material damage in many cases, consequently there has been a remarkable dearth of injurious outbreaks, particularly in the early part of the year and presumably largely due to this cause.

The San José seale, Aspidiotus perniciosus Comst., continues to be one of our most serious insect pests. It is gratifying to state that a number of our more progressive fruit growers at least have learned to control this insect in a very satisfactory manner. There is a strong tendency on the part of many to adhere to a lime-sulphur wash rather than to make extensive treatments with mineral oils or preparations of the same, despite the fact that some of these last named materials have been pushed vigorously by certain commercial agencies. The backward season had a very pronounced effect on the development of the grape root worm, Fidia viticida Walsh. Normally, this species transforms to the pupa from about June 1st to the 20th, the full grown larvæ being near the surface some days at least before pupation occurs. Observations made July 10 resulted in finding only a few recently transformed pupæ on light soil, whereas under normal conditions the beetles would have appeared two or three weeks earlier. There has been on the whole a distinct improvement in conditions over those obtaining a few years past, though it should be borne in mind that there is always danger of serious injury by this pest in restricted areas. The apple leaf folder, Ancylus nubeculana Clem. is normally rare in New York state orchards. It was so abundant in Cattaraugus County last September as to lead to the report that it was doing considerable damage to apple trees in that vicinity.

Our attention was called the last of July to the unusual abundance of a comparatively unknown form, namely, Epizeuxis denticularis Harvey. This species was so abundant at Palenville, Greene County, N. Y., that hundreds were observed upon the walls of the kitchen and they were also very numerous about the barn and other out-buildings. It is very probable, considering that the larva of the closely related $E$. lubricalis Geyer feeds upon grass, that the caterpillar of this species may have similar habits, though it is possible that it may subsist upon dried vegetation, as has been recorded of $E$. aemula Hübn. The evidence at hand would seem to favor the latter conclusion, as the moths were very abundant in buildings where there was presumably a goodly supply of dried provender upon which the eaterpillars could subsist. Should such prove to be the case, this species should be classed with the much better known clover-hay worm, Hypsopygia costalis Fab. as a species liable to injure stored hay. 
Several shade tree pests have excited considerable interest because of their serious depredations. The white marked tussock moth, Hemerocampa leucostigma Sm. \& Abb., defoliated trees in a number of cities and villages in New York state, and would undoubtedly have caused more injury had it not been checked by local work in various communities. The elm leaf beetle, Galerucella luteola Müll., was exceedingly destructive to the elms of Albany and Troy in 1906. An extended injury in 1907 was prevented only by thorough and extensive spraying. The sugar maple borer, Plagionotus speciosus Say must be ranked as one of our most injurious species, as observations show that it is seriously injuring young maples here and there throughout the state. It is abundant enough in some localities to threaten the existence of long rows of nice young trees.

Forest insects have oceasioned considerable anxiety in certain parts of the state. The green striped maple worm, Anisota rubicunda Fabr., was very abundant over several square miles of forest land in southern Rensselaer County, defoliating tracts of sugar maples acres in extent. The operations of this insect were first observed in 1906, at which time approximately eight or ten acres were badly injured. The past season these trees were entirely stripped of foliage, and maples here and there over a considerable area lost a goodly proportion of their leaves. This species was assisted in its destructive work by what we have designated as the antlered maple caterpillar, Heterocampa gutivitta Walk., a species which was evidently very numerous, judging from the specimens submitted for examination. Certain of the beech forests in the Catskills suffered from an outbreak by the snowwhite linden moth, Ennomos subsignarius Hübn., the caterpillars being numerous enough to strip most of the trees over an area about a mile long and ranging from one eighth to one fourth of a mile in width. An unusual injury was the destruction of some 2,500 to 3,000 one and two year old white and Scotch pine seedlings in the state nurseries located in the Adirondacks. The injury, so far as observations could be determined, was caused entirely by white grubs, presumably those of our common northern form, Lachnosterna fusca Fröhl.

\title{
A BRIEF SUMMARY OF THE MORE IMPORTANT INJU- RIOUS INSECTS OF LOUISIANA
}

\author{
By Wilmon Newell and Arthur H. Rosenfeld, Baton Rouge, La.
}

Louisiana, with her combination of semi-tropical and temperate climates and plants and the consequent variety of natural enemies of the latter, is of great interest entomologically. For many years ships from foreign countries have been entering the port of New Orleans, 


\section{$2 \mathrm{BHL}$ Biodiversity Heritage Library}

Felt, Ephraim Porter. 1908. "Entomological notes for 1907." Journal of economic entomology 1(2), 148-150. https://doi.org/10.1093/jee/1.2.148.

View This Item Online: https://www.biodiversitylibrary.org/item/37189

DOI: https://doi.org/10.1093/jee/1.2.148

Permalink: https://www.biodiversitylibrary.org/partpdf/325844

\section{Holding Institution}

New York Botanical Garden, LuEsther T. Mertz Library

\section{Sponsored by}

The LuEsther T Mertz Library, the New York Botanical Garden

\section{Copyright \& Reuse}

Copyright Status: NOT_IN_COPYRIGHT

This document was created from content at the Biodiversity Heritage Library, the world's largest open access digital library for biodiversity literature and archives. Visit BHL at https://www.biodiversitylibrary.org. 